\title{
Social representations of globalisation and the functioning of the metasystem in social comparison contexts: evidence from two studies in Portugal
}

\author{
Raquel Ribeiro ${ }^{1}$ (D) \\ Gabrielle Poeschl2 (D)
}

\begin{abstract}
Globalisation generates intense debate and contradictory positions, being a particularly relevant object of social representations (SR). This article attempts to better understand the SR of globalisation by analysing how the normative social metasystem controls, verifies and selects the material produced by the operative system in contexts of social comparison. Using a multi-method approach, we conducted two studies, with semi-structured interviews $(\mathrm{N}=30)$ and a free association questionnaire $(\mathrm{N}=100)$, in the Porto Metropolitan Area, Portugal. Results highlight how social comparison contexts trigger arguments in favour of group interests and reveal the existing power relations between groups. The importance of identifying the relations that guide thinking about social objects and the applicability of SR theory for understanding complex, controversial, sociopolitical objects are discussed.
\end{abstract}

Keywords: globalisation; social representations; metasystem; social comparison; social identity

\section{Introduction ${ }^{3}$}

Globalisation has been one of the big issues of the last three decades, dominating editorial, political, and academic life (Held and McGrew, 2007; Milanovic, 2016; Reich, 1998). Despite numerous publications on this theme, there is no consensus about the definition of globalisation, what it includes, when it started, or even what its effects are. The only point of agreement appears to be the difficulty inherent in its definition (Kumar,

\footnotetext{
${ }^{1}$ Centre for Social Studies of the University of Coimbra. Coimbra (BL), Portugal.

E-mail: <raquelribeiro@ces.uc.pt>.

2 Faculty of Psychology and Educational Sciences, University of Porto. Center of Psychology at the University of Porto. Porto (DL), Portugal. E-mail: <gpoeschl@fpce.up.pt>.

${ }^{3}$ Raquel Ribeiro gratefully acknowledges the financial support provided by the Portuguese Foundation of Science and Technology - FCT - to the development of her Doctoral Thesis at the Faculty of Psychology and Educational Sciences of the University of Porto (fellowship SFRH/BD/19261/2004) and to her research at the Centre for Social Studies of the University of Coimbra (DL57/2016/CP1341/CT0030). Grateful thanks are due to all those who participated in the studies and those who made possible the data collection. Thanks are also due to those who commented on earlier versions of this paper, and to two anonymous reviewers. Usual disclaimers apply.
} 
2003), making globalisation one of the most controversial topics of the Social Sciences (Guillén, 2001).

For some authors, globalisation is inherently positive, a promoter of welfare, development, and progress (e.g., Chambre de Commerce Internationale [CCI], 2003); for others it has, on the contrary, promoted the growth of inequalities between and/or within nations, strengthening the global hierarchies of privilege, control and exclusion (e.g., Stiglitz, 2002; Milanovic, 2016), providing an arena for conflict between social groups (Santos, 2006); for others still, globalisation is a dialectical process whose 'outcome is not necessarily, or even usually, a generalized set of changes acting in a uniform direction, but consists in mutually opposed tendencies' (Giddens, 1990, p. 64).

The spread of the word 'globalisation' in non-specialised contexts, the frequent debates about the phenomenon and the importance of its real or inferred consequences, make it a particularly relevant object of social representations. By social representations, we mean 'a set of concepts, statements and explanations originating in daily life in the course of inter-individual communications' (Moscovici, 1981, p. 181). Thus, social representations theory (SRT, e.g., Moscovici, 1976, 1981), as a psychosociological theory of knowledge (Jodelet, 2011), aims at understanding the processes by which people come to a shared understanding of the social world and how this knowledge relates to their ability to act on it. As argued by Elcheroth, Doise and Reicher (2011), insofar as it allows a study of the processes of communication and social influence, conformity, and resistance, harmony, or conflict between groups, SRT is a privileged theoretical framework for the study of sociopolitical phenomena such as globalisation.

In this article we intend to illustrate the interrelationships between the sociopsychological and economic processes guiding opinions about globalisation by following Doise's (1990) approach to the study of social representations. For Doise (1990), to understand how and why social representations of a given object are formed, it is necessary to understand what social rules, norms and expectations guide the social thinking about that object, i.e., to identify how the normative social metasystem controls, verifies, and selects the material produced by the cognitive operative system.

First, we present the concept of metasystem of SR proposed by Moscovici (1976). Then we attempt to deepen the understanding of the social representations of globalisation (e.g., Poeschl and Viaud, 2008; Viaud, 2007) by analysing the intra-individual variations in discourses about the phenomena that are produced in contexts of social comparison triggered by attribution tasks or, according to Elcheroth, Doise, and Reicher (2011), the meta-knowledge about globalisation - 'what we think that other people think' (p. 739). Finally, we discuss the importance of identifying the relationships that guide the thinking about a particular social object to the understanding of sociopolitical phenomena. 


\section{The metasystem of social representations}

Fifty years ago, Moscovici (1976) proposed the concept of social representation to support his proposal of a 'psychosociology' of knowledge (Jodelet, 2011). Moscovici was concerned with understanding social life from a psychological perspective, in particular, how scientific and ideological discourses infiltrate 'natural' or common sense thinking, how they become part of our heritage, thinking, languages and practices (Moscovici, 1976, 1981). An understanding of social life from a psychological perspective constitutes a prerequisite for understanding the influence of social relationships on psychological processes (Duveen and Lloyd, 1990). According to Moscovici (1976), in common thought, as in scientific thinking, two cognitive systems are involved: an operative system that makes associations, inclusions, discriminations, deductions and a metasystem that controls, verifies, selects the matter produced by the former. The metasystem of social representation is composed of 'normative relationships that control, check, direct' individual cognitive operations (Moscovici, 1976, p. 254), using multiple organising schemes, such as scenarios and rules, and relevant norms for each situation that govern the different social interactions in which individuals participate. These societal schemes are pre-existing to individual cognitive functioning and are activated according to the demands of specific situations (Doise, 1990). Thus, the two systems (normative social metasystem and individual cognitive operative system) establish a top-down process in individual cognition (Wagner and Hayes, 2005).

Activation and use of the standards, rules and expectations of the metasystem will depend both on the social context and its situational needs, and on the position occupied by social groups (Staerklé and Doise, 2005). Situational needs may, for example, require a rigorous application of logical principles in a particular scientific domain, or they may favour the defence of group cohesion (Doise, 1990). Thus, the normative relationships that compose the metasystem may explain the intra-individual and the inter-individual variations in the discourses produced, and the social regulations which influence cognitive functioning may be analysed at different levels, in particular at the intra-individual, interindividual, positional, ideological levels (Doise and Valentim, 2015). The coexistence, in the same individuals, of several modes of thought and thereby knowledge, determines a state of cognitive polyphasia (Moscovici, 1976), as the activation of different rules manifests itself in changes, even central ones, in the social representations produced in different social contexts (see also Jovchelovitch, 2008; Menin, 2006).

\section{The functioning of the metasystem}

The metasystem has received little attention in the SRT literature. The first description of the functioning of the metasystem may be found in Moscovici's (1976) seminal work about the social representations of psychoanalysis where he showed how the 
metasystem functions in the anchoring process - generally defined as the process that allows something unfamiliar and disturbing to be embedded into our pre-existing structure of categories (Moscovici, 1976, 1981; see also Doise, 1992 for a discussion on the different levels of anchoring). To exemplify, Moscovici found that Catholics adapted the new object to Christian values, adopting a non-positivistic view of psychoanalysis, stressing the similarity between the therapeutic process and 'confession', as well as the positive role of affectivity; communists, by contrast, rejected psychoanalysis, considering it a reactionary, 'American' science, a tool for the depoliticisation of man and a bourgeois creation that had to be opposed (Moscovici, 1976).

Following the work of Moscovici, several studies have illustrated the functioning of the metasystem, even if the authors made no direct reference to it. Before turning more specifically to the research on globalisation, we present here a set of studies showing how the metasystem functions to shape and modulate the representations of social objects in order to protect individuals' personal and social identity, in accord with social identity theory (Tajfel and Turner, 1986, see also Rosenmann, Reese and Cameron, 2016, for a development concerning social identity approach to the study of globalisation).

\section{Social identity and self-enhancement}

In a study on the social representations of the profession of researcher, Lage (1978) showed that the dominant, official discourse on television and in textbooks was expressed in a fairly accurate way by students of the upper classes, whose academic route may lead to a profession related to science. By contrast, students in vocational schools, to whom this route was closed, rejected this normative discourse; the representation of scientists presented by these students was a caricature, functioning as a sort of consolation for their position of 'inferiority'. The differential selection of notions used for the formation of social representations (Lage, 1978) reveals how the metasystem works to protect individuals' positive social identity.

Similarly, Poeschl $(1992,1998)$ studying social representations of intelligence, showed that apprentices, who could not give too much importance to intellectual or scholarly skills because of their successive failures in school, placed greater value on sociability and socio-cultural activities. By contrast, high school pupils who were invested in their studies gave considerable importance to academic skills and success.

Moreover, Miguel, Valentim, and Carugati (2010), when comparing the social representations of intelligence provided by students, parents, and teachers, highlighted how group membership determines the abilities and dimensions valued in intelligence, thereby conferring social validation to individuals' social roles. However, both parents and teachers tended to value dimensions that were not directly related to their own particular roles, when considering family and school roles in promoting the development of children's 
intelligence, in order to protect their personal and social identity in the event of their children's failure.

\section{Social differentiation and intergroup relations}

The functioning of the metasystem may also be observed when different situations of social comparison are salient. For instance, in her research on the social representations of intelligence, Poeschl (1992) observed how group identification produced modifications in the social representations formed in order to positively differentiate the in-group from the out-group. These studies examined various contexts of comparison (human vs. machine, human vs. animal, man vs. woman). Results showed that comparisons: between man and machine, stressed the importance of creativity in the definitions of human intelligence; between species, led to enhancement of the cognitive skills in the definition of human intelligence and their devaluation in the definition of animal intelligence (Poeschl, 2001); between man and woman, created specific representational dimensions: femininity in feminine intelligence and social success in masculine intelligence (Poeschl, 1999).

In the above-mentioned study, Poeschl (1992, 1998) also asked pupils and professionals to rate the dimensions of intelligence as they thought psychologists and teachers would do. Results seemed to reflect the relationship between the respondents and the psychologists: the tensions existing between school psychologists and teachers were revealed by the fact that teachers considered that psychologists did not value the skills they strove to develop. In contrast, the good relationships existing between school psychologists and apprentices were reflected by apprentices' opinions that psychologists valued the dimension of intelligence (sociability and socio-cultural activities) that they themselves considered important.

Using data from Moscovici's work on the diffusion of psychoanalysis, Gillespie (2008) showed how interviewees talked about the views that others had about psychoanalysis and that social representations were built upon these 'alternative representations', i.e., representations of other people's representations (Gillespie, 2008, p. 376). For instance, the representation of psychoanalysis formed by the communists was built upon the dismissal of the alternative representation, the representation attributed to psychoanalysts:

Psychoanalysis claims to be a therapy, or even a worldview (amongst other things, it claims to be able to explain the origin and development of society in terms of conflict with the libido). It is in fact a falsifying tool that uses socalled complexes to cover up social conflicts (Moscovici, cit. in Gillespie, 2008, p. 383). 
According to Gillespie these attributed representations are usually depreciated representations, open to questioning and critique, evidencing the nature of the relations between groups.

\section{Self-presentation}

The study of the 'mute zone' of social representations (e.g., Abric, 2003; Guimelli and Deschamps, 2000) has shown that some elements of a representation are not expressed in classical conditions of evocation because they are 'counter-normative' i.e., they express cognitions or beliefs that are in conflict with moral values and group norms. To capture these elements of representation, one of the techniques used to reduce the normative pressure is to ask respondents to speak for themselves and next to speak for others, for instance members of their in-group (see also Menin, 2006). Using this technique of substitution, Deschamps and Guimelli (2004) asked respondents to list their own answers and the answers of the 'French in general' with regard to insecurity. They found that, in their own answers, respondents listed feelings and emotions such as 'fear', 'danger', 'accident', 'uncertainty', 'weakness', or 'disease'. The most frequent associations attributed to the 'French in general' referred mainly to causes of insecurity, such as 'suburbs', 'young', 'drug', 'foreigners' and 'unemployment'. In the opinion of the authors, the context 'French in general' reduced the normative, politically correct pressure, making possible the emergence of responses that did not appear under 'normal' condition (i.e., were previously mute) because they were not socially accepted or incompatible with the values and norms of the reference group.

Another study, using the same technique to capture the social representations of Gypsies, showed that words with more negative connotations, such as 'thefts', 'dirty', 'beggars', 'foreigners', 'non-workers', 'vulgarity', were more frequent in the substitution condition than in the 'normal' condition (Guimelli and Deschamps, 2000). Similarly, Valencia, Gil-De-Montes and Elejabarrieta (2004) found that immigrants were more positively evaluated in the 'normal' condition than under substitution conditions.

The results of these studies highlight, as Flament (1999) stated, 'how social representations are largely (if not totally) the complex reflection of several normative models' (p. 50). They support the idea that the implicit representation of values, social space and human relationships held by individuals influence the development of their operative reasoning (Moscovici, 1976); this leads to a selection (i.e., a self-censorship) of the content of the representations in order to best meet the social expectations, norms and rules salient at a given moment, such as rationality, self-presentation, selfenhancement, group cohesion, social differentiation, etc.

The modulations produced by different situational needs are highlighted in a study developed by Gillespie (2007). In this study, conducted by means of interviews, the author asked tourists about the changes occurring in Ladakh (India), and showed that, in an 
attempt to positively differentiate themselves from other tourists, viewed as disrespectful, interviewees resorted to 'othering' (defining themselves as travellers, as opposed to the others, the tourists): 'I think travellers are people who go to a country to appreciate the culture, and I think tourists go to a country to be voyeurs' (Gillespie, 2007, p. 585). However, later in the interview, they reported having adopted the same kind of behaviours that they had criticized before: 'We are completely observers, we are not part of it', 'We don't know what is going on, I think it's voyeurism.' (Gillespie, 2007, p. 586). Other interviewees, in an attempt to repair the uncomfortable and unpredicted identification with the derogated other tourists, slightly changed their former arguments criticizing behaviour in response to the needs of self-presentation: 'I mean we still partook in stuff going on there, we just did it more limited and we did other stuff as well' (Gillespie, 2007, p. 587).

These studies show that an analysis of the functioning of the metasystem is possible through the use of various techniques, such as substitution (Abric, 2003; Poeschl, 1992) and the direct or the indirect comparison between groups (Poeschl, 1998, 1999, 2001).

\section{Globalisation as an object of social representations}

The popularity that globalisation has acquired in the scientific community (and beyond) explains the large number of publications on the subject (Reich, 1998). However, to our knowledge, apart from an international research developed to capture the social representations of globalisation (see Poeschl and Viaud, 2008; Viaud, 2007), globalisation has only recently started to receive attention in psychological research (see Chiu et al., 2011; Reese, Rosenmann, and McGarty, 2015).

Research on social representations of globalisation was initiated in 2003, with a study conducted by means of a questionnaire with 503 students from France, Portugal, Tunisia, Brazil, and Mexico. Students were asked to respond to a set of opinion scales on favourability, concern, and possible involvement in globalisation (for more details see Viaud, 2007). Applying the methodology developed by Doise and colleagues (e.g., Doise, Clémence, and Lorenzi-Cioldi, 1992) to identify different positions on social objects, Poeschl, Campos, and Ben Alaya (2007) identified three contrasting positions in relation to globalisation: (i) supporters - the most favourable and the least concerned respondents, who viewed themselves as better informed and who most strongly believed in the possibility of individual action on globalisation; (ii) opponents - the least favourable, who felt most threatened and concerned, but who most strongly believed in the possibility of collective action; and (iii) indifferents - moderately favourable but the least informed and concerned, who believed the least in possible action, either personally or collectively. In the context of the five countries surveyed, Portugal and Brazil were represented predominantly in the group of supporters, while French students from Aix-en-Provence made up the majority of opponents. Students from Mexico-City and Brest (France) were 
principally represented in the group of indifferents, and students from Tunis were divided between supporters and opponents (Poeschl, Campos, and Ben Alaya, 2007). The discourse of the supporters, gathered by a task of free association, referred mainly to technological progress as an element of civilization, the process of unification, and the society of communication; the discourse of the opponents mentioned Americanisation and loss of identity, the opposition between rich and poor, between market and labour, and American capitalism; the discourse of the indifferents was centred on trade, market and work (Viaud, Uribe, and Acosta, 2007).

In 2005, another study was conducted in the five countries that also included active professionals in the sample (Poeschl and Viaud, 2008). The results obtained were similar, in terms of both the distribution of the national groups and the content of the evocations associated with the three positions. The consistency of both the positioning between countries and the structure of the captured representations suggested that national affiliations, countries' rank on the world stage, and the history of the conflicts between them, were important organisers of the discourse and determinants of positioning on globalisation. For instance, the following strong associations could be noted for the different representations: for French - between the capitalist economy and 'United States of America (US)', 'inequalities', but also cultural 'standardisation' and 'loss of identity' and for Mexican - between 'poverty' and 'power' and economic liberalism. The ambivalence of Tunisian representations was reflected in the presence of 'domination' and 'development', which seemed to refer back to fears of domination during their colonial past (Ben Alaya and Campos, 2007; Campos, 2008).

Following these studies, Poeschl and Ribeiro (in press, see also Ribeiro, 2011) conducted a study by means of a free association task with the word 'globalisation' using the substitution technique (Abric, 2003), to examine how respondents shape others' representations in order to achieve a positive social differentiation (e.g., Tajfel and Turner, 1986). More specifically, they compared the representations of globalisation of 85 Portuguese students attending first year higher education courses in Psychology ${ }^{4}$, that were expressed, firstly, in the absence of a given context of evocation ("When you hear the word 'globalisation' what are the five words or expressions that come to your mind?"), with the representations they attributed to 'students from China' and to 'students from the US' ("When they hear the word 'globalisation' what are, in your opinion, the five words or expressions that come spontaneously to the mind of these students?").

Globally, 1146 responses were registered, among which 201 different words with a frequency of occurrence varying from 1 (64 words) to 59. In respondents' own views on globalisation, the most frequent words listed (by more than $10 \%$ of the respondents) were: 'world', 'union', 'uniform', 'equality', 'development', 'global village', 'proximity', 'global' and 'economy'. By contrast, in respondents' views attributed to students from China, the most

\footnotetext{
${ }^{4}$ Seven men and 78 women, aged between 19 and 32 years $(M=20.09$ years, $S D=2.06), 10.6 \%$ having a part-time professional activity of less than 18 hours per week.
} 
frequent words included 'development', 'economy', 'emigration', 'world', 'power', 'expansion', 'technology' and 'exportation', whereas the words most often attributed to students from the US were 'power', 'dominance', 'economy', 'world', 'development', 'expansion', 'culture', 'trade' and 'superiority'.

The chi-square test $(p<.05)$ revealed that the students associated more often with their own conception of globalisation the words 'world', 'union', 'standardisation', 'equality', 'global village' and 'proximity' whereas in the conceptions attributed to the Chinese and, more particularly, to the US students, they included more often the words 'power' and 'dominance'. On the other hand, 'emigration' appeared more frequently in Chinese students' than in respondents' own representations.

With regard to the responses to the positioning variables (about favourability, concern, and involvement with globalisation), respondents stated that the students from the US were more favourable to and involved in globalisation than the students from China or themselves, and that the Chinese students were more concerned by globalisation than the students from the US or themselves.

In spite of the limitations of the study, namely the small number of respondents and the convenience sample procedure that does not allow generalizations to the population (Creswell, 2003; Tashakkori and Teddlie, 1998), results suggested that the context of social comparison influenced individual cognitive functioning so that the social representations produced positively distinguished the in-group from the other groups. Indeed, the representations attributed to the other students were less positive than respondents' own representations, in line with results of studies in which representations attributed to other people were at stake (e.g., Gillespie, 2008; Guimelli and Deschamps, 2000; Valencia, Gil-de-Montes, and Elejabarrieta, 2004). Respondents attributed to the US students a conception of globalisation that was mainly a form of power and of economic and cultural domination by the US over other countries, and viewed thexxse students as favourable to and involved in the process. They also considered that students from China associated globalisation with power and dominance but, in this case, above all, as a possibility of expansion, either by leaving the country or by exporting Chinese products. The fact that emigration implies leaving the country, associated with a high degree of uncertainty, might explain why respondents considered that globalisation was a source of concern for the Chinese students.

The results illustrate how the metasystem works to respond to the requirements of the situation by activating different normative principles. Self-presentation needs, which activate normative standards of social desirability, seemed to be at work when respondents gave their own opinion on globalisation. Indeed, according to social desirability standards, it is preferable to present oneself as pleasant and friendly rather than aggressive and selfish (e.g., Dubois, 2005). The representations attributed to others reflected the perceived power relationships between countries and suggested a motivation to give a more negative image to other national groups than to ones' own national group. The 
positive and altruistic discourse found when respondents gave their own opinion contrasted with the self-interested discourse of domination attributed to other students, especially US students, evidencing a need to positively differentiate the in-group from the out-groups, as shown in the studies conducted by Poeschl (1991, 1999, 2001) and Gillespie (2008). Because the social representations captured did not seem to question or contest globalisation, they also appeared to fulfil a status quo justification function, legitimising the existing social arrangements (cf. Jost and Ignatow, 2001).

\section{Globalisation and national positions}

Following the study described above, we decided to go further in the understanding of the social representations of globalisation and in the analysis of the functioning of the metasystem in contexts of social comparison produced by attribution tasks. Adopting a multi-method approach (Creswell, 2003; Tashakkori and Teddlie, 1998) two studies were conducted: a first study by semi-structured interviews and a second study through a questionnaire of free association of words and closed items.

\section{STUDY 1}

In the first study we conducted 30 semi-structured interviews in which interviewees from the Porto Metropolitan Area (Portugal) were asked to respond to an attribution task presenting three contexts of social comparison: the opinion on globalisation they attributed to Chinese people, to North Americans, and to Africans. In line with results of Poeschl and Ribeiro (in press), we expected to find a discourse about globalisation that stressed dominance, power and favourability for the North Americans, and dominance, power and ambivalence for the Chinese people. With regard to Africans, we did not have precise expectations regarding the way how the social regulations would operate. To assess whether those representations were influenced by the need to achieve a positive distinctiveness, at the end of the interview we asked respondents to indicate five words that, in their own view, best characterize globalisation.

\section{Method}

\section{Respondents}

Fifteen men and 15 women from the Porto Metropolitan Area, Portugal, aged between 18 and 58 years $(M=34.30$ years, $S D=12.13)$ participated in this study. One third (10) of the participants were students attending higher education courses in Psychology, Law, Nursing, Management, and Engineering. The other two thirds (20) were professionals: $47.6 \%$ senior and middle managers and $42.9 \%$ employees in administration 
and services or in commerce and industry. Half of the participants completed secondary education, $13.3 \%$ compulsory schooling and $36.7 \%$ higher education.

The respondents were recruited through a non-probability convenience sampling procedure with stratification for sex and professional activity. Although this sampling procedure does not allow generalization of results to the population (Creswell, 2003; Tashakkori and Teddlie, 1998) it is appropriate for the objectives of the study, namely to generate insight and in-depth understanding (Patton, 2002).

\section{Instrument and procedure}

After presenting the objectives of the study and having obtained the consent for participation and recording, we asked respondents to answer several questions on globalisation organized in five parts (cf. Ribeiro, 2011): general opinion on globalisation; definition and characterisation of the phenomenon; positions of North American, Chinese and African people about globalisation; role of globalisation in world inequalities; and possible action. In this article, we analyse the questions addressed in the third part of the interview.

More specifically, we asked interviewees whether they considered that everyone in the world had the same opinion on globalisation and what they thought was the opinion about globalisation of North American, African, and Chinese people. If interviewees responded that there are different opinions about globalisation, we asked about the motives that justify these divergences.

At the end of the interview, in the small questionnaire aimed at collecting sociodemographic data, we asked respondents to indicate five words that, in their own view, best characterize globalisation.

The interviews were conducted at the residences of the respondents or at the University during the year 2007. The average duration of the interviews was of about an hour, going from a minimum of 45 minutes up to 2 hours.

\section{Data analysis}

The material collected from the interviews was transcribed and then analysed by means of the program Alceste for the analysis of textual data. This program analyses the formal structure of the co-occurrence of the words in a given corpus, performing a descending classification analysis using the chi-square distance (e.g., Reinert, 1993), thus enabling an interpretation in terms of specific ways of thinking. An Alceste Portuguese dictionary was used to avoid data analysis errors. The words and sentences presented in this article were translated into English from the Alceste outputs in Portuguese. 


\section{Results and discussion}

All words with a frequency of at least three occurrences were included in the analysis with the Alceste software. Of the 543 Elementary Context Units (ECU, corresponding more or less to a sentence) that constituted this part of the interview (corresponding to $9.38 \%$ of the global corpus) $38.7 \%$ were classified, suggesting a high degree of heterogeneity in the discourses that composed this part of the interview. Three classes of words were extracted referring respectively to the opinions attributed to the Chinese, North American and African people.

\section{Opinions attributed to the Chinese people (class 1)}

The first class was composed of $129 \mathrm{ECU}, 61.43 \%$ of the corpus, and referred mainly to 'culture' $\left(\chi^{2}=30.95\right)$ and ambivalent opinions: 'negative', 'positive', 'opinion', 'closed', and 'perspective' $\left(\chi^{2}>5.00\right)$.

The most representative sentences suggested that people had different opinions on globalisation mainly because of their cultural differences:

No one thinks in the same way ... all people are different even at the cultural level, different cultures see things differently, so not everyone has the same opinion (male student of Engineering); I think some people think that globalisation is positive and others that it is negative, it varies from one culture to another culture (female student of Psychology);

I think that above all, it is a question of cultural factors, the way I see the world will influence whether or not I like it (female student of Law).

Interviewees also considered that the Chinese people had a positive opinion of globalisation in relation to commercial expansion:

I think the Chinese have a good opinion of globalisation, in the American perspective, that is, as a market for exports, but they are only slowly allowing the entrance of new goods (female student of Law);

Every day you see more Chinese shops in Portugal and more Chinese and this causes them to have other rights that, if there was no globalisation, they would not have (female student of Psychology).

On the contrary, they considered that Chinese people would have a negative opinion in relation to culture:

The Chinese are a very closed people, they emigrate to other countries and maintain their customs, they shut themselves off (male student of Engineering); 
With regard to the cultural aspect and customs I think they think like me, that globalisation brings negative aspects ... they [the Chinese] do not let people interfere much in their habits, their customs ... in this respect ... I think they see globalisation as a negative aspect (male insurance professional).

\section{Opinions attributed to the North Americans (class 2)}

In the second class, which included 49 ECU, i.e., $23.33 \%$ of the corpus, we found among the most frequent words: 'world', 'duty', 'rest' $\left(\chi^{2}>20.00\right)$, 'bigger', 'the United States', 'large', 'Europe', and 'well' $\left(\chi^{2}>10.00\right)$.

The analysis of the most representative elementary context units revealed that interviewees considered that North Americans were in favour of globalisation because of their dominant position in the world:

Perhaps they [the Americans] are favourable; those who think that globalisation, in general, is beneficial and have an interest ... are powerful, and because they are the most powerful, the leaders, or they think they are the leaders of the world ... maybe they think that it is a benefit for them (female administrative assistant);

I find that they think correctly because, in fact, they are on the top of the world, aren't they? They rule the world, it is commonly said, and therefore they must think about it [globalisation] fairly well, isn't that so? (male employee).

On the other hand, respondents seemed to view the North Americans as egocentric, only concerned with what happens in the US:

What matters to them is what is happening to them ... they are indifferent to what is happening in the rest of the world, isn't that right? ... If you ask an American where Portugal is located, most of them do not know where it is. ... They think they are the centre of the universe and sometimes do not want to know what's going on in the rest of the world. What happens there, happens there. We are the 'leaders of the world!', and do not look to what happens next door (female museum assistant);

They think they have the power, they have the knife and have the cheese, have everything ... they meddle in everything, they think they own the world! (male employee). 
The third class, with 32 ECU (15.24\% of the units) comprised mainly the words: 'situation', 'days', 'fear', 'convinced' $\left(\chi^{2}>28.00\right)$, 'oil', 'take', 'process', 'misery', 'poverty', 'Angola', 'food', 'talking', 'African', 'conditions', 'opportunity', and 'knowing' ( $\left.\chi^{2}>10.00\right)$.

The discourse suggested that Africans fear globalisation. This opinion was justified by the lack of information Africans may have about the phenomenon:

Maybe they have a bit of fear because they do not know what it will bring them, although they need all the help they can get. There are African people living in extreme poverty ... maybe they are much less informed than us, maybe they should need to know what benefits it [globalisation] could bring to them (male security guard).

Some interviewees considered that globalisation had not yet reached the African continent: 'I also believe that there are people so poor, so poor, so poor that globalisation for them is not a reality yet' (male financial director).

Others stated that Africans' underdevelopment is due not to a lack of resources but to corruption and exploitation:

[Africa] is such a rich area, so rich in ore, coal ... see Angola, it is a country that has everything, lacks nothing, oil, has everything (male middle manager); corrupt political regimes, exploitation of the resources by the world's great powers, poverty, hunger, disease, the overview is tragic, it's tragic, millions of people die each year from hunger in Africa (male university professor).

Interviewees seemed to agree that globalisation is an opportunity for Africans:

We have some African countries negotiating in terms of oil ... I am convinced that some of these countries are beginning to see the phenomenon of globalisation as something positive in the sense that it will bring them some additional business, development, ability to create value (male financial director).

\section{Respondents' own conceptions}

With regard to respondents' conceptions, the words most often listed (by more than $10 \%$ of the interviewees) in the small questionnaire handed out at the end of the interview, included: 'development' (10), 'economy' (10), 'union' (6), 'information' (6), 'global village' (4), 'knowledge' (4), 'communication' (4), 'culture' (4), 'free movement' (4), 'sharing' (4), 'equality' (3), 'inequality' (3), 'evolution' (3), 'integration' (3), 'exchange' (3), 'opportunity' (3), 'solidarity' (3), 'technology' (3) and 'uniform'(3). These words were 
similar to those found in previous studies (Ben Alaya and Campos, 2007; Campos, 2008; Viaud, Uribe, and Acosta, 2007; Poeschl and Ribeiro, in press; Ribeiro, 2011).

In line with our expectations, results suggested that the social representations of globalisation were modulated by different norms and expectations according to situational needs. The rules triggered by the metasystem betrayed a certain antagonism to the North American and Chinese people while revealing some sympathy for the Africans, considered poor but deserving of a better condition.

Also, as expected, results highlighted that a favourable opinion was attributed to North Americans, justified by the powerful and dominant position of the United States in world affairs, not only at the economic but also at the cultural level (Americanisation). Results also highlighted Chinese economic dominance and made it possible to understand better the ambivalent attitude attributed to the Chinese people in the study of Poeschl and Ribeiro (in press). In fact, ambivalence is explained by the economic gains that globalisation brings to Chinese economic expansion and openness, and by the threat it poses to the age-old Chinese culture and customs.

When referring to the position of Africans, even if interviewees seemed to agree that globalisation would be beneficial to the continent and a source of opportunities, they considered that Africans may fear globalisation. They justified this possible negative attitude toward the phenomenon by the lack of information available and by the uncertain consequences the phenomenon may bring.

The comparison with interviewees' own representations of globalisation, presented in the free association task at the end of the interviews, suggested that this comparison influenced individual cognitive functioning, leading to the formation of social representations enabling a positive distinctiveness of the in-group in comparison with outgroups. This result is in line with the social identification approach (Tajfel and Turner, 1986) and with previous studies on social representations conducted in contexts of social comparison (e.g., Gillespie, 2008; Miguel, Valentim, and Carugati, 2010; Poeschl, 1992, 2001).

The several studies conducted in Portugal on the social representations of globalisation (e.g., Coelho, 2008; Poeschl, Campos and Ben Alaya, 2007; Ribeiro and Poeschl, 2013) highlighted a globally positive representation grounded on a process of unification at the global scale, driven by changes to the economy, communications and technology. Although it was also possible to find different positions, concerns and perceived consequences of globalisation among the inquired respondents (e.g., Coelho, 2008; Poeschl, Campos, and Ben Alaya, 2007; Ribeiro, 2011) anchored in participants' social positions, experiences and interests in globalisation (e.g., Ribeiro, 2011; Ribeiro and Poeschl, 2013), these were not associated with fundamentally different representations of the phenomenon. The idea of a united world may stem from the Portuguese maritime discoveries of the 15th and 16th centuries, that some authors consider the beginning of the process of globalisation (Rodrigues and Devezas, 2007); discoveries are highly 
regarded by the Portuguese (e.g., Liu et al., 2009) and may possibly constitute a central element of their social identity.

Results concerning the social representations of globalisation attributed to other national groups highlight how positive distinctiveness is obtained through ascribing different motivations that are closely connected with the social rank of the nations. In the social representations of globalisation attributed to North Americans, it is possible to observe that self-interested motives are negatively evaluated, interpreted as selfish, selfcentred and oppressive, deriving from the dominant position of the United States in world economy and culture. In the social representations attributed to Chinese people, motives of economic self-interest are also present, stressing export growth and the proliferation of Chinese shops. Other negative aspects that enable a positive distinctiveness are related to cultural factors: the closed, isolated, society of China, as opposed to the sharing and unity of the Portuguese. In the representations attributed to Africans, a group that is perceived as having lower status than the in-group and a lack of power to influence world affairs, positive distinctiveness is obtained by attributing fragilities and fears, e.g., the fear that globalisation triggers through its uncertain consequences. Conversely to higher status groups, in the representations attributed to Africans, self-interested motives are positively evaluated, as an opportunity for development and as a necessity to fight poverty that exists because of prevalent corruption and exploration. The opposite assessment of selfinterest highlights, as showed by Gillespie (2007), that the need to protect personal and social identity leads to a social differentiation that is hypocritical.

The results underline the importance of social-historical-political frameworks, social positions and social identities in the formation and expression of social representations (Miguel, Valentim and Carugati, 2016), namely those of globalisation. They support the non-neutrality of social representations and the way representations are born within and legitimize (or otherwise contest) existing power relations (Voelklein and Howarth, 2005). Moreover, they show that the neoliberal ideological framework prevailing in globalisation (e.g., Stiglitz, 2002), characterized by a preponderance of self-interested pursuits, is also present in lay people's social representations (see Griva and Chryssochoou (2015) on anchoring of Greeks' views of globalisation in political right-left-wing ideology). However, and in line with the studies about the 'mute zone' of social representations (Abric, 2003; Guimelli and Deschamps, 2000), self-interest seems to be counter-normative to the inquired Portuguese respondents, since it only becomes visible in the representations attributed to other countries.

\section{STUDY 2}

In the last few years, important changes have occurred in the world socialhistorical-political framework. In the Presidency of the United States, George W. Bush gave way to the first Afro-American President, Barack Obama (2009-2017) - the living 
embodiment of the American Dream - and to the rise of hope and of freedom from all types of oppression (Charteris-Black, 2011). It was however followed by the election of Donald Trump and of his vision of 'America first' as the way to be 'great again', possibly resulting in a backlash and questioning of the future of globalisation (Seidel and Chandy, 2016). On the other hand, China has been among the world's fastest-growing economies and has overtaken the US as the world's largest economy (on a purchasing power parity basis), according to the International Monetary Fund 2014 data (Morrison, 2019). The global financial crisis of 2007 affected severely the European Union. After this shock, with damaging consequences for southern Eurozone countries, Portugal has achieved economic recovery to pre-crisis levels in 2018, with $36 \%$ of Portuguese being satisfied with the situation of the Portuguese economy compared to 10\% in 2007 (European Commission, 2008 , 2018). However, the European Union project suffered an important setback with the United Kingdom exit decision. The world also faces other important global crises such as the refugee crisis and the climate crisis.

In order to understand how the changes in the social-historical-political framework impacted the formation and expression of the social representations of globalisation we replicated the study with university students described above (Poeschl and Ribeiro, in press) using the substitution technique (Abric, 2003). We expected to observe variations in the social representations of globalisation that reveal the changes occurring in the relations between countries and that illustrate the above described socio-cognitive processes. More specifically, we expected that the formation and expression of people's own representations, and of the representations attributed to others, would reflect selfpresentation effects and a need for a positively valued distinctiveness.

\section{Method}

\section{Respondents}

One hundred and forty-two first year higher education Psychology students from the Porto Metropolitan Area in Portugal answered the questionnaire. The present analysis includes the 100 respondents of Portuguese nationality, 17 males and 83 females aged between 18 and 41 years $(M=18.92$ years, $S D=2.55)$. A small percentage $(4 \%)$ of the students also had a part-time professional activity of less than 18 hours per week.

\section{Instrument and procedure}

The study was conducted by means of a questionnaire made up of open and closed items following the structure of Poeschl and Ribeiro (in press). After presenting the objectives of the study and having obtained informed consent, we asked participants to fulfil a task of free association of words: "When you hear the word 'globalisation' what are 
the five words or expressions that come to your mind?" followed by a set of opinion scales on favourability, concern, and possible involvement in globalisation (cf. Viaud, 2007). Participants were then asked to answer the same questions as they thought 'students from China' and 'students from the US' would answer. The order of presentation of the stimuli was counterbalanced. Finally, socio-demographic data were gathered (gender, age, nationality, professional activity and political orientation).

The questionnaire was completed by participants during a regular class in November 2019.

Data analysis

The words evoked in the free association were recorded in a data file applying the reduction rules generally used in these tasks (Rosenberg and Jones, 1972); some obvious synonyms were also grouped. The most frequent words were analysed and the frequency of their association with students' own opinion and the opinion attributed to students from China and to students from the US were compared by means of the chi-square statistic. Descriptive statistics were calculated for closed item questions. Following the procedures proposed by Tabachnick and Fidell (2007), the influence of outliers was reduced by altering extreme values and missing answers were replaced by group means. The ratings on the positioning variables were averaged by respondent to provide reliable scales on concern (Cronbach's alpha: own opinion $=.67$; students from China $=.57$; students from US = .74) and involvement in globalisation (own opinion:.41; students from China $=.62$; students from US $=.65$ ). Differences between students' opinion and the opinion attributed to other students were assessed by repeated measures ANOVA. All statistical analyses were performed using the IBM SPSS Statistics software v. 25.

\section{Results and discussion}

Globally, 1228 words were collected in the free association task, among which 255 different words with a frequency of occurrence varying from 1 (131 words) to 68 (culture). In respondents' own information on globalisation, the words most often listed (by more than $10 \%$ of the respondents) were 'world', 'culture', 'internet', communication', 'information', 'trade', 'union', 'expansion', and 'technology'. By contrast, for responses attributed to students from China: 'trade', 'culture', 'technology', 'pollution', 'knowledge', 'economy', 'development', and 'opportunity'; and for responses attributed to students from the US: 'culture', 'economy', 'trade', 'power', 'technology', and 'immigration'. The chisquare test $(p<.05)$ revealed that the words students associated more often with their own conception of globalisation were 'world', 'internet', 'communication', and 'union'; whereas 'power' and 'immigration' appeared more often in conceptions attributed to the students from US and 'pollution' and 'opportunity' in Chinese students' representations. 
With regard to the responses to the positioning variables (favourability, concern, and involvement), respondents considered themselves more favourable to globalisation than students from China, and believed that Chinese students were more concerned by globalisation than students from the US or themselves. There were no significant differences concerning involvement (see Table 1):

Table 1

Positioning variables in relation to globalisation Means and standard deviations (in parentheses)

\begin{tabular}{|l|c|c|c|c|}
\hline & Own opinion & Students from China & Students from the US & \multirow{F}{*|}{ F } \\
\hline Favourability & $\begin{array}{c}5.15 \mathrm{a} \\
(1.08)\end{array}$ & $\begin{array}{c}4.52 \mathrm{~b} \\
(1.45)\end{array}$ & $\begin{array}{c}4.80 \mathrm{ab} \\
(1.55)\end{array}$ & $5.67 * *$ \\
\hline Concern & $\begin{array}{l}3.44 \mathrm{a} \\
(1.25)\end{array}$ & $\begin{array}{c}4.22 \mathrm{~b} \\
(1.23)\end{array}$ & $\begin{array}{c}3.64 \mathrm{a} \\
(1.58)\end{array}$ & $10.56 * * *$ \\
\hline Involvement & $\begin{array}{c}4.57 \\
(0.86)\end{array}$ & $(0.98)$ & $(1.11)$ & 0.22 \\
\hline
\end{tabular}

Source: Self-produced based on 2019 questionnaire data.

Note: $*: p \leq 0.05 ; * *: p \leq 0.01 ; * * *: p \leq 0.001$;

Different letters in each line indicate significantly different means.

In comparison with results from the 2007 study (Poeschl and Ribeiro, in press), although it is possible to find several changes in the most frequent words (see Table 2), those changes do not suggest a radical transformation of the social representations of globalisation. In Portuguese students' own representation, the unification process (associated with the words: uniform, global village, proximity) conducive to development and equality at a global scale, seems to lose importance in relation to a world united through culture, communication, internet, trade, and technology. In the representations attributed to the other students, 'power' and 'dominance' still appear as negative aspects (Gillespie, 2008; Guimelli and Deschamps, 2000; Valencia, Gil-De-Montes, and Elejabarrieta, 2004), although with less importance. Other negative facets came to light, related to the negative consequences of economic development and supremacy: 'pollution' for Chinese students and 'immigration' for US students.

The words associated with globalisation: (i) corroborate the decrease in favourability and involvement observed in the opinion attributed to the students from the US; (ii) highlight the increase in Portuguese students' favourability; and (iii) confirm the ambivalent attitude attributed to Chinese students already found in 2007 (see Figure 1). 
Table 2

Most frequent words about globalisation

\begin{tabular}{|c|c|c|c|c|c|c|c|c|c|c|c|c|}
\hline & \multicolumn{4}{|c|}{2007} & \multicolumn{4}{|c|}{2019} & \multicolumn{4}{|c|}{ Total } \\
\hline & $\begin{array}{l}\text { Own } \\
\text { opinion }\end{array}$ & $\begin{array}{c}\text { Students } \\
\text { China }\end{array}$ & $\begin{array}{c}\text { Students } \\
\text { US }\end{array}$ & $x^{2}$ & $\begin{array}{l}\text { Own } \\
\text { opinion }\end{array}$ & $\begin{array}{l}\text { Students } \\
\text { China }\end{array}$ & $\begin{array}{c}\text { Students } \\
\text { US }\end{array}$ & $x^{2}$ & Total & 2007 & 2019 & $x^{2}$ \\
\hline Culture & 7 & 7 & 9 & 0.35 & 25 & 21 & 22 & 0.38 & 91 & 23 & 68 & $15.66 * * *$ \\
\hline Trade & 5 & 7 & 9 & 1.14 & 14 & 28 & 18 & 5.20 & 81 & 21 & 60 & $13.07 * * *$ \\
\hline Technology & 6 & 9 & 4 & 2.00 & 10 & 17 & 16 & 2.00 & 62 & 19 & 43 & $5.84 *$ \\
\hline Economy & 9 & 12 & 17 & 2.58 & 9 & 12 & 19 & 3.95 & 78 & 38 & 40 & 0.24 \\
\hline World & $35 a$ & $10 b$ & $14 b$ & $18.34 * * *$ & $26 a$ & $2 b$ & $5 b$ & $31.09 * * *$ & 92 & 59 & 33 & $12.25 * * *$ \\
\hline Information & 7 & 3 & 4 & - & $14 a$ & $8 b$ & $9 b$ & 2.00 & 45 & 14 & 31 & $3.99 *$ \\
\hline Internet & 4 & 5 & 6 & 0.40 & $20 a$ & $2 b$ & $7 b$ & $17.86 * * *$ & 45 & 15 & 29 & 2.27 \\
\hline Communication & 8 & 2 & 4 & - & $18 a$ & $3 b$ & $6 b$ & $14.00 * * *$ & 41 & 14 & 27 & 2.30 \\
\hline Development & 13 & 15 & 13 & 0.20 & 4 & 10 & 9 & 2.70 & 64 & 41 & 23 & $8.46^{* *}$ \\
\hline Power & $1 a$ & $10 b$ & $24 c$ & $23.03 * * *$ & $0 a$ & $4 a$ & $16 b$ & $20.80 * * *$ & 55 & 35 & 20 & $6.93 *$ \\
\hline Expansion & 7 & 9 & 10 & 0.54 & 12 & 7 & 4 & 4.26 & 49 & 26 & 23 & 1.00 \\
\hline Knowledge & 4 & 2 & 6 & - & 6 & 12 & 4 & 4.73 & 34 & 12 & 22 & 1.55 \\
\hline Union & $22 a$ & $6 b$ & $5 b$ & $16.55 * * *$ & $13 a$ & $3 b$ & $2 b$ & $12.33 * * *$ & 51 & 33 & 18 & $7.23 * *$ \\
\hline Pollution & 3 & 2 & 0 & - & $2 a$ & $13 b$ & $3 a$ & $12.33 * * *$ & 23 & 5 & 18 & $5.43 *$ \\
\hline Equality & $17 a$ & $3 b$ & $2 b$ & $19.18^{* * *}$ & 9 & 5 & 3 & 3.29 & 39 & 22 & 17 & 1.72 \\
\hline Immigration & 0 & 0 & 2 & - & $2 a$ & $1 a$ & $14 b$ & $18.47 * * *$ & 19 & 2 & 17 & $9.60 * *$ \\
\hline Dominance & $1 a$ & $7 b$ & $18 c$ & $17.15^{* * *}$ & 0 & 4 & 7 & - & 37 & 26 & 11 & $8.81^{* *}$ \\
\hline Emigration & $2 a$ & $11 b$ & $4 a b$ & $7.88^{*}$ & 2 & 8 & 0 & - & 27 & 17 & 10 & 3.15 \\
\hline Standardization & $21 a$ & $3 b$ & $6 b$ & $18.60 * * *$ & 3 & 2 & 2 & - & 37 & 30 & 7 & $18.39 * * *$ \\
\hline Global & 10 & 5 & 4 & 3.26 & 5 & 1 & 1 & - & 26 & 19 & 7 & $7.71^{* *}$ \\
\hline Proximity & $11 a$ & $2 b$ & $3 b$ & $9.13 *$ & 4 & 2 & 1 & - & 23 & 16 & 7 & $5.17 *$ \\
\hline Global village & $12 a$ & $2 b$ & $3 b$ & $10.71 * * *$ & 6 & 0 & 0 & - & 23 & 17 & 6 & $7.24 * *$ \\
\hline Exportation & 0 & 9 & 4 & - & 0 & 5 & 1 & - & 19 & 13 & 6 & $3.86 *$ \\
\hline Opportunity & 1 & 6 & 4 & - & 2 & 10 & 3 & $7.60 *$ & 26 & 11 & 15 & 0.14 \\
\hline Superiority & 0 & 1 & 9 & - & 0 & 0 & 4 & - & 15 & 10 & 4 & 3.66 \\
\hline
\end{tabular}

Source: 2007 (Poeschl and Ribeiro, in press); 2019 (Self-produced based on 2019 questionnaire data).

Note: $* p \leq 0.05 ; * *: p \leq 0.01 ; * * *: p \leq 0.001$;

Different letters in each line indicate significantly different occurrences. 


\section{Figure 1}

Positioning variables in relation to globalization

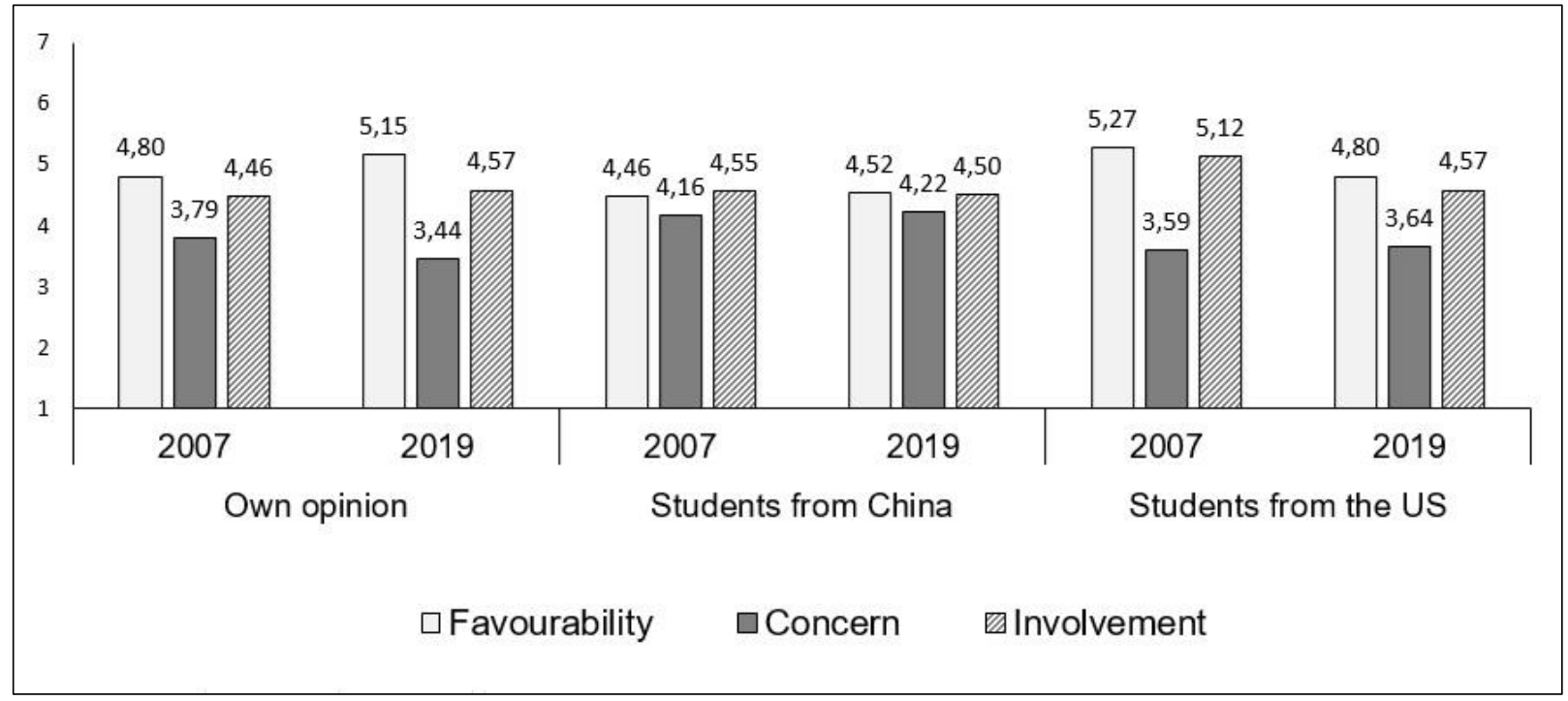

Source: 2007 (Poeschl and Ribeiro, in press); 2019 (Self-produced based on 2019 questionnaire data). Means $(1=$ not at all; $7=$ very much $)$.

These results highlight the changes in the power relations between China and the US and the wider social-political context. Although international surveys claim that the levels of confidence in the presidency of Donald Trump are not very different from those observed for George W. Bush (e.g., Bialik, 2018), the representations attributed to the students from the US reflect the increasingly negative tone of Trump's political discourse (Drake and Kiley, 2019). The observed decrease in favourability may be due to the escalation of trade disagreements with China and views of Chinese economic power as a 'critical threat' to US interests (McCarthy, 2019; Morrison, 2019), to the low tolerance of immigration policy reified in the wall along the US-Mexico border, or to the criticism and disrespect for international agreements and institutions (Vinha, 2017).

The representations attributed to the students from China are also in line with the evolution of the Chinese position in the world. In spite of the fact that China's economic power has grown significantly since 2007 , economic growth has slowed down from $14.2 \%$ in 2007 to $6.6 \%$ in 2018 . The policies implemented to produce rapid economic growth have entailed a number of costs, such as heavy pollution and the widening of income inequality threatening its sustainability (Morrison, 2019). Lastly, the increased favourability of the inquired Portuguese students may be due to their relatively optimistic opinion of the Portuguese economy, in comparison with 2007 (European Commission, 2008, 2018). Moreover, it may also result from a series of events (2019 World's Best Destination according to the World Travel Awards; winner of the 2017 Eurovision Song Contest and of the 2016 UEFA European Championship) and from public policies (e.g., the 'Golden Visa' - 
RAQUEL RIBEIRO; GABRIELLE POESCHL

residence permit for investment activity in Portugal) that have made Portugal a globallyattractive destination for travel, study and residence.

Results are thus in line with expectations: they reveal the changes that occurred in the relations between countries and, at the same time, illustrate self-presentation effects and a need for a positive distinctiveness.

\section{Conclusions}

In this article we followed the perspective of Doise (1990) according to which the study of the common sense knowledge of a given social object consists in studying the relationship between social regulations and cognitive functioning. For this purpose, we analysed how the representations of globalisation were modulated by the functioning of a normative metasystem in contexts of social comparison triggered by attribution tasks.

Results revealed how the social regulations of the metasystem work to preserve individuals' personal and social identity (Tajfel and Turner, 1986) and differentiate positively the in-group in a context of intergroup comparison, in line with previous research on social representations (Gillespie, 2007, 2008; Miguel, Valentim, and Carugati, 2010; Poeschl, 1992, 1998, 1999, 2001). As we have shown, when the Portuguese respondents from the Porto Metropolitan Area gave their own opinion about globalisation, they described it as a phenomenon which, through the increasingly entangled networks of economic, cultural and communications activity, should lead to a more unified world. In contrast, and in comparison with their own discourse, respondents attributed more opportunistic conceptions to higher status groups, such as North American or Chinese people. The focus of the attributed perspectives was on power and dominance, either cultural, political or economic, without references to the unification process. Respondents achieved a positive distinctiveness from these social groups by attributing to others a more self-interested vision of globalisation, which contrasted with their own altruistic discourse. When the conceptions of a lower status group were evoked, out-group self-interested motives - that also constituted in-group interests - were justified by offering a legitimate opportunity for development, highlighting the hypocritical nature of the social differentiation strategy adopted (Gillespie, 2007). Positive distinctiveness from this social group was obtained by giving voice to fears and fragilities that, in one's own group representation, were largely overlooked. In fact, if explicitly asked about the emotions they felt in relation to globalisation, Portuguese respondents declared that they experience positive emotions (e.g., curiosity, hope) with more intensity than negative emotions (e.g., helplessness, revolt), but fear was felt with the same intensity as confidence (Ribeiro, 2011).

Changing the context of evocation makes it possible to highlight how the metasystem works to respond to the requirements of a situation, and illustrates how the same individuals can make use of different rules, even opposing ones, according to the occasion (Doise, 1990). It also makes it possible to observe the dialogicality of social 
representations (Smith, O'Connor, and Joffe, 2015) of globalisation, in which opposite polarities coexist, built upon a social-political-historical context of unequal power relations.

It may be further noted that the social representations attributed to the different social groups differ from the results of international surveys on globalisation. For example, the 2007 Pew Global Attitudes survey (Kohut and Wike, 2008) showed that enthusiasm for economic globalisation had decreased, especially in the richest western nations and that, on the contrary, the most favourable views on economic globalisation came from the world's poorest regions, namely sub-Saharan Africa. In the 2016 survey, $60 \%$ of Chinese people agreed that global economic engagement was positive compared to only $44 \%$ of Americans (Stokes, 2016). This illustrates how social representations are fluid, contextual constructions that fulfil different functions and answer different needs in social life (see also Jovchelovitch, 2008). As Wagner and Kronberger (2001) have put it, they 'are socially constructed, culturally correct in their own sense and functional in everyday social life' ( $p$. 148). Through a process that is simultaneously cognitive and social, but also cultural and ideological, they fill the gap between the known and the inexplicable, the unknown (Voelklein and Howarth, 2005).

Our results illustrate the applicability of SRT for the understanding of sociopolitical objects and underline the importance of identifying the social relations that guide thinking about a particular social object. This is particularly significant considering the importance of globalisation for intergroup relations and the way social representations govern actions and behaviours (Moscovici, 2001). In fact, several studies have shown how opposing social representations are associated with support or rejection of State policies of regulation and solidarity. For instance, Clémence et al. (1994) studied the representation of social solidarity in Switzerland and how this representation modulated the positions regarding social assistance to particular social groups. They concluded that the support given to social assistance increased to the same extent as the perceived tensions in Swiss society. Griva and Chryssochoou (2015) have shown how perceptions of globalisation as global modernisation and cooperation related positively with agreement with pro-right-wing state policies (e.g., increase of policing is necessary for the security of citizens) while global power inequalities were associated with agreement with pro-left-wing state policies.

Further studies are necessary to better understand how social representations of globalisation, or of other controversial political and economic objects, are determined by social-historical ideological frameworks; how they fulfil different functions in the present; how they orientate individual behaviour in different ways (inaction, acceptance, protest, prejudice, violence, etc.); and what are their implications for the future political, economic and social relations between countries. In addition to being fundamental for social representations theory development (Elcheroth, Doise, and Reicher, 2011; Miguel, Valentim, and Carugati, 2016; Voelklein and Howarth, 2005), given the magnitude and accelerating pace of global changes, such studies are urgent if the Social Sciences want to make a contribution to (the possibility of) making a better and fairer world. 


\section{Bibliographical references}

ABRIC, J. C. La recherche du noyau central et de la zone muette des représentations sociales. In: ABRIC, J. C. (ed.). Méthodes d'étude des représentations sociales. Saint-Agne: ÉRÉS, 2003.

Ben AlayA, D.; Campos, P. H. F. "La représentation sociale de la mondialisation: contenu, structure et organisation". Bulletin de Psychologie, vol. 60, nº 1, p. 35-47, 2007.

BIALIK, K. "How the world views the U.S. and its president in 9 charts" (online). 2018. Available at: <https://www.pewresearch.org/fact-tank/2018/10/09/how-the-world-views-the-u-s-and-itspresident-in-9-charts/>. Access in: 10 Dec. 2019.

CAMPOS, P. H. F. La représentation sociale de la mondialisation: son image, ses promesses, ses illusions. In: POESCHL, G.; VIAUD, J. (eds.). Images de la mondialisation: la construction sociale d'une représentation. Rennes: Presses Universitaires de Rennes, 2008.

Chambre de Commerce Internationale. "Nouvelles données sur la mondialisation, la pauvreté et la répartition des revenus" (online), 2003. Available at: <http://www.iccwbo.org>. Access in: 8 Oct. 2005.

CHARTERIS-BLACK, J. Politicians and rhetoric: the persuasive power of metaphor. London: Palgrave Macmillan UK, 2011.

CHIU, C., et al. "Toward a social psychology of globalization". Journal of Social Issues, vol. 67 no 4, p. 663-676, 2011.

CLÉMENCE, A., et al. Solidarités sociales en Suisse. Lausanne: Réalités Sociales, 1994.

CoelHo, M. "Representações sociais da globalização: posicionamento e consequências". Porto, Portugal. Master's Dissertation. Faculty of Psychology and Educational Sciences, University of Porto, 2008.

CRESWELL, J. W. Research design: qualitative, quantitative, and mixed methods approaches. Thousand Oaks: Sage, 2003.

DESCHAMPS, J. C.; GUIMELLI, C. L'organisation interne des représentations sociales de la sécurité/insécurité et l'hypothèse de la "zone muette". In: BEAVOIS, J. L.; JOULE, R. V.; MonTEIL, J. M. (eds.). Perspectives cognitives et conduites sociale. Rennes: Presses Universitaires de Rennes, 2004.

Doise, W. Les représentations sociales. In: GHiglione, R.; BONnEt, C.; Richard, J. F. (eds.). Traité de psychologie cognitive. Paris: Dunod, 1990.

. "L'ancrage dans les études sur les représentations sociales". Bulletin de Psychologie, vol. 45, p. 189-195, 1992.

Doise, W.; CLemenCE, A.; LORENZI-CiOldi, F. Représentations sociales et analyses de données. Grenoble: Presses Universitaires de Grenoble, 1992.

DoISE, W.; VAlentim, J. P. Levels of analysis in social psychology. In: WRIGHT, J. D. (ed.). International encyclopedia of the social \& behavioral sciences, vol. 13, 2nd ed. Oxford: Elsevier, 2015.

DRAKE, B.; KILEY, J. "Americans say the nation's political debate has grown more toxic and 'heated' rhetoric could lead to violence" (online). 2019. Available at: <https://www.pewresearch.org/facttank/2019/07/18/americans-say-the-nations-political-debate-has-grown-more-toxic-and-heatedrhetoric-could-lead-to-violence/>. Access in: 18 Jul. 2019. 
DuBois, N. "Normes sociales de jugement et valeur: ancrage sur l'utilité et ancrage sur la désirabilité". Revue Internationale de Psychologie Sociale, vol. 18 no 3, p. 43-79, 2005.

DUVEEN, G.; LLOYD, B. Social representations and the development of knowledge. Cambridge: Cambridge University Press, 1990.

ElCheroth, G.; Doise, W.; Reicher, S. "On the knowledge of politics and the politics of knowledge: how a social representations approach helps us rethink the subject of political psychology". Political Psychology, vol. 32 no 5, p. 729-758, 2011.

EUROPEAN COMMISSION. "Eurobarometer 68: public opinion in the European Union" (online), 2008. Available at:

<https://ec.europa.eu/commfrontoffice/publicopinion/archives/eb/eb68/eb_68_en.pdf> Access in: 29 Nov. 2019

. "Standard Eurobarometer 90: public opinion in the European Union" (online), 2018.

Available at: <http://data.europa.eu/88u/dataset/S2215_90_3_STD90_ENG>. Access in: 29 Nov. 2019.

FLAMENT, C. "La représentation sociale comme système normatif". Psychologie et Société, vol. 1, p. 29-53, 1999.

Giddens, A. The consequences of modernity. Cambridge: Polity Press, 1990.

GillesPIE, A. "Collapsing self/other positions: identification through differentiation". British Journal of Social Psychology, vol. 46 no 3, p. 579-595, 2007.

. "Social representations, alternative representations and semantic barriers". Journal for the Theory of Social Behaviour, vol. 38 no 4, p. 375-391, 2008.

GRIVA, A.-M.; ChRYSSOCHOOU, X. "Debating globalization: perceptions of the phenomenon based on political positioning and on ideological understandings of economy, culture, and the nation-state". European Journal of Social Psychology, vol. 45, p. 880-895, 2015.

GuILLÉN, M. F. "Is globalisation civilizing, destructive or feeble? A critique of five key debates in the social-science literature". Annual Review of Sociology, vol. 27, p. 235-260, 2001.

Guimelli, C.; Deschamps, J. C. "Effet des contextes sur la production d'associations verbales. Le cas des représentations sociales des Gitanes". Les Cahiers Internationaux de Psychologie Sociale, vol. 47 , p. 44-54, 2000.

HeLd, D.; McGrew, A. Globalization theory: approaches and controversies. Cambridge: Polity Press, 2007.

JODELET, D. "Returning to past features of Serge Moscovici's theory to feed the future". Papers on Social Representations, vol. 20, 2011.

Jost, J. T.; IGNATOW, G. What we do and don't know about the functions of social representations. In: DeAuX, K.; PhilogÊne, G. (eds.). Representations of the social. Oxford: Blackwell, 2001.

JOVCHELOVITCH, S. "The rehabilitation of common sense: social representations, science and cognitive polyphasia". Journal for the Theory of Social Behaviour, vol. 38 no 4, p. 431-448, 2008.

Kohut, A.; Wike, R. "PEW PRESENTS... Assessing globalisation: benefits and drawbacks of trade and integration". Harvard International Review, vol. 30, no 1, p. 70-74, 2008.

KUMAR, V. S. A. "A critical methodology of globalisation: politics of the 21st century?". Indiana Journal of Global Legal Studies, vol. 10, no 2, p. 87-111, 2003. 
RAQUEL RIBEIRO; GABRIELLE POESCHL

LAGE, E. "Les représentations sociales du métier de chercheur dans la jeunesse". Rapport scientifique de I'Action Thématique Programmée du C.N.R.S. Contrat C.N.R.S. no 2156, 1978.

LIU, J. H., et al. "Representing world history in the 21st century: the impact of 9/11, the Iraq War, and the Nation-State on dynamics of collective remembering". Journal of Cross-Cultural Psychology, vol. 40, no 4, p. 667-692, 2009.

MCCARTHY, J. "Americans' favorable views of China take 12-point hit" (online), 2019. Available at: <https://news.gallup.com/poll/247559/americans-favorable-views-china-point-hit.aspx>. Access in: 28 Nov. 2019.

Menin, M. S. S. "Representação social e estereótipo: a zona muda das representações sociais". Psicologia: Teoria e Pesquisa, vol. 22, nº 1, p. 43-52, 2006.

Miguel, I.; Valentim, J. P.; Carugati, F. "Intelligence and its development: social representations and social identities". Papers on Social Representations, vol. 19, n² 2, 2010.

. "De las representaciones sociales a la acción: proximidad y relación entre las representaciones sociales del desarrollo de la inteligencia y un estilo parental democrático". Revista de Psicología Social, vol. 31, nº 2, p. 254-281, 2016.

MiLANOvic, B. Global inequality: a new approach for the age of globalization. Cambridge: Harvard University Press, 2016.

MORRISON, W. M. "China's economic rise: history, trends, challenges, and implications for the United States" (online), 2019. Available at: <https://fas.org/sgp/crs/row/RL33534.pdf>. Access in: 26 Nov. 2019.

Moscovici, S. La psychanalyse, son image et son public. Paris: Presses Universitaires de France. (original work published in 1961), 1976.

. On social representations. In: FoRGAS, J. P. (ed.). Social cognition: perspectives on everyday understanding. London: Academic Press, 1981.

. Why a theory of social representations? In: Deaux, K. and Philogène, G. (eds.). Representations of the social. Oxford: Blackwell, pp. 8-35, 2001.

PATTON, M. Q. Qualitative research \& evaluation methods, 3rd ed. Thousand Oaks: Sage, 2002.

POESCHL, G. "L'intelligence: un concept à la recherche d'un sens". Doctoral Thesis. Faculté de Psychologie et des Sciences de L'Éducation. Université de Genève, Genéve, Suisse, 1992.

. "Processus d'ancrage et représentations sociales de l'intelligence". Psicologia, vol. 12, no 1, p. 85-100, 1998.

. Intelligence masculine et intelligence féminine. In: BRIL, B., et al. (eds.). Propos sur l'enfant et l'adolescent: quels enfants, pour quelles cultures? Paris: L'Harmattan, 1999.

. "Social comparison and differentiation strategies in social representations of intelligence". Swiss Journal of Psychology, vol. 60 no 1, p. 15-26, 2001.

Poeschl, G.; Campos, P. H. F.; Ben Alaya, D. "Appartenances nationales et prises de position sur la mondialisation". Bulletin de Psychologie, vol. 60, no 1, p. 11-19, 2007.

POESCHL, G.; RIBEIRO, R. "Inserções sociais e tomadas de posição: efeito das pertenças sociais nas representações da globalização". In: Valentim, J. P. (ed.). Representações sociais: para um conhecimento do pensamento quotidiano. In press. 
POESCHL, G.; VIAUD, J. (eds.). Images de la mondialisation: la construction sociale d'une représentation. Rennes: Presses Universitaires de Rennes, 2008.

ReESE, G.; Rosenmann, A.; MCGaRTY, C. "Globalisation and global concern: developing a social psychology of human responses to global challenges". European Journal of Social Psychology, vol. 45, p. 799-805, 2015.

REICH, S. "What is globalisation? Four possible answers" (Working Paper no 261) (online), 1998. Available at: <https://kellogg.nd.edu/publications/workingpapers/WPS/261.pdf>. Access in: 23 May 2005.

ReinerT, M. "Les "mondes lexicaux" et leur "logique" à travers l'analyse statistique d'un corpus de récits de cauchemars". Langage et Société, vol. 66, p. 5-39, 1993.

RibeIRo, R. Representações da globalização, justiça e relações entre países: um contributo para o estudo do metassistema das representações sociais (unpublished doctoral thesis in psychology). Faculty of Psychology and Educational Sciences, University of Porto, Portugal, 2011.

Ribeiro, R.; PoESCHL, G. "Globalização e suas consequências: representações de estudantes e profissionais portugueses". Psicologia e Saber Social, vol. 2, nº 1, p. 51-71, 2013.

Rodrigues, J. N.; DeVEZAS, T. Pioneers of globalization: why the Portuguese surprised the world. Famalicão: Centro Atlântico, 2007.

ROSENBERG, S.; JONES, R. "A method for investigating and representing a person's implicit personality theory: Theodore Dreiser's view of people". Journal of Personality and Social Psychology, vol. 22, p. 372-386, 1972.

Rosenmann, A.; Reese, G.; Cameron, J. E. "Social identities in a globalized world: challenges and opportunities for collective action". Perspectives on Psychological Science, vol. 11, no 2, p. 202-221, 2016.

SANTOS, B. S. "Globalisations". Theory, Culture \& Society, vol. 23, no 2-3, p. 393-399, 2006.

SeIDEL, B.; CHANDY, L. "Donald Trump and the future of globalization" (online). Brookings, 2016. Available at: <https://www.brookings.edu/blog/up-front/2016/11/18/donald-trump-and-the-futureof-globalization/>. Access in: 25 Feb. 2018.

SMITH, N.; O'CONNOR, C.; JofFE, H. "Social representations of threatening phenomena: the self-other thema and identity protection". Papers on Social Representations, vol. 24, no 2, p. 1-23, 2015.

STARKLÉ, C.; DOISE, W. Ethic of rights and ethic of duties: societal change and stability in everyday thinking. In: PirTiLlA-BACKMAN, A.-M., et al. (eds.). Values, morality and society. Helsinki, Finland: Gaudeamus, 2005.

Stiglitz, J. E. Globalisation and its discontents. New York: W.W. Norton \& Company, 2002.

STOKES, B. "Unlike the West, India and China embrace globalization" (online), 2016. Available at: $<$ https://yaleglobal.yale.edu/content/unlike-west-india-and-china-embrace-globalization>. Access in: 21 Oct. 2019.

TABACHNiCK, B. G.; FidelL, L. S. Using multivariate statistics, 5th ed. Boston: Allyn \& Bacon/Pearson, 2007.

TAJFEL, H.; TURNER, J. C. The social identity theory of intergroup behavior. In: WORCHEL, S.; AUSTIN, W. G. (eds.). The psychology of intergroup relations. Chicago: Nelson-Hall, 1986. 
RAQUEL RIBEIRO; GABRIELLE POESCHL

Tashakkori, A.; Teddlie, C. Mixed methodology. Thousand Oaks: Sage, 1998.

Valencia, J-F.; Gil-De-Montes, L.; ElejabarrietA, F. "Creencias y actitudes hacia la inmigración: estereotipos, prejuicio y regulaciones normativas". Revista de Psicología Social, vol. 19, no 3, p. 299-318, 2004.

VIAUD, J. "Les représentations sociales de la mondialisation, projet et originalités d'une recherche internationale". Bulletin de Psychologie, vol. 60, no 1, p. 3-10, 2007.

ViAud, J.; URiBE, J.; AcostA, T. "Représentations et lieux communs de la mondialisation". Bulletin de Psychologie, vol. 60, no 1, p. 21-33, 2007.

ViNHA, L. "Previsivelmente incoerente: uma análise preliminar da política externa de Donald Trump". Relações Internacionais, vol. 55, p. 9-33, 2017.

VOELKLEIN, C.; HOWARTH, C. "A review of controversies about social representations theory: a British debate". Culture and Psychology, vol. 11, no 4, p. 431-454, 2005.

WAGNER, W.; HAYES, N. Everyday discourse and common sense: the theory of social representations. New York: Palgrave Macmillan, 2005.

WAGner, W.; KRONBerger, N. Killer tomatoes! Collective symbolic coping with biotechnology. In: DeAuX, K.; Philogène, G. (eds.). Representations of the social. Oxford: Blackwell, 2001.

\section{Resumo}

Representações sociais da globalização e o funcionamento do metassistema em contextos de comparação social: evidência de dois estudos em Portugal

A globalização gera intensos debates e posições contraditórias, sendo um objeto particularmente relevante de representações sociais (RS). Este artigo procura compreender melhor as RS da globalização, analisando como o metassistema social normativo controla, verifica e seleciona o material produzido pelo sistema operativo em contextos de comparação social. Recorrendo a uma abordagem multimétodo, realizamos dois estudos, com entrevistas semiestruturadas $(\mathrm{N}=30)$ e um questionário de associação livre de palavras $(\mathrm{N}=100)$, na área metropolitana do Porto, em Portugal. Os resultados evidenciam como os contextos de comparação social desencadeiam argumentos em favor dos interesses do grupo e revelam as relações de poder existentes entre grupos. Discute-se a importância de identificar as relações que norteiam o pensamento sobre um dado objeto social, bem como a aplicabilidade da teoria das RS para a compreensão de objetos sociopolíticos complexos e controversos.

Palavras-chave: globalização; representações sociais; metassistema; comparação social; identidade social

\section{Resumen}

Las representaciones sociales de la globalización y el funcionamiento del metasistema en contextos de comparación social: evidencias de dos estudios realizados en Portugal

La globalización genera debates intensos y posiciones contradictorias, siendo un objeto particularmente relevante de las representaciones sociales (RS). Este artículo procura comprender mejor las RS de la globalización analizando de qué formas el metasistema social normativo controla, verifica y selecciona el material producido por el sistema operativo en contextos de comparación social. Utilizando un enfoque de métodos múltiples hemos realizado dos estudios mediante entrevistas semiestructuradas $(\mathrm{N}=30)$ y un cuestionario de asociación libre de palabras $(\mathrm{N}=100)$, en el área metropolitana de Porto, Portugal. Los resultados muestran que los contextos de comparación social desencadenan argumentos a favor de intereses grupales y revelan las relaciones de poder existentes entre grupos. A partir de aquí discutimos la importancia de identificar las relaciones que guían el 
pensamiento sobre un objeto social así como la aplicabilidad de la teoría de las RS para la comprensión de objetos sociopolíticos complejos y controvertidos.

Palabras clave: globalización; representaciones sociales; metasistema; comparación social; identidad social

\section{Résumé}

Représentations sociales de la mondialisation et fonctionnement du métasystème en contextes de comparaison sociale: contribution de deux études menées au Portugal

La mondialisation génère des débats intenses et des positions contradictoires, étant un objet particulièrement pertinent de représentations sociales (RS). Cet article tente de mieux comprendre les RS de la mondialisation en analysant comment le métasystème social normatif contrôle, vérifie et sélectionne le matériel produit par le système opératoire en contextes de comparaison sociale. Utilisant une approche multi-méthode, nous avons réalisé deux études, par entretiens semi-structurés $(\mathrm{N}=30)$ et un questionnaire d'association libre de mots $(\mathrm{N}=100)$, dans la zone métropolitaine de Porto, Portugal. Les résultats montrent comment les contextes de comparaison sociale activent des arguments en faveur des intérêts du groupe et révèlent les relations de pouvoir existantes entre groupes. L'importance d'identifier les relations qui guident la réflexion sur un objet social particulier est discutée, ainsi que l'applicabilité de la théorie des RS pour la compréhension d'objets sociopolitiques complexes et controversés.

Mots-clés: mondialisation; représentations sociales; métasystème; comparaison sociale; identité sociale 